\title{
Liquids treated by Atmospheric Pressure Plasma Jet for bone cancer therapy
}

\author{
Premio Congreso SIBB 2017
}

\author{
I. HAMOUDA ${ }^{1,2}$, J. GUILLEM-MARTI ${ }^{1,2}$, M.P. GINEBRA ${ }^{1,2}$, C. CANAL ${ }^{1,2}$ \\ ${ }^{1}$ Biomaterials, Biomechanics and Tissue Engineering Group, Dpt. Materials Science and Metallurgy, Technical \\ University of Catalonia (UPC), Barcelona \\ ${ }^{2}$ Barcelona Research Center in Multiscale Science and Engineering, \\ Universitat Politècnica de Catalunya, Barcelona
}

\begin{abstract}
Current bone cancer treatments include and may combine surgery, chemotherapy, radiation therapy or cryosurgery among others. However, these treatments are not completely effective and unspecific where patients relapse. In recent years, researchers have found a novel approach by means of cold atmospheric plasma that can selectively treat cancer cells without damaging the surrounding tissues but its effects on bone cancer are unknown. Cold plasmas generate reactive oxygen and nitrogen species in air, which seem to be related to their effects on cells. As biological tissues and cells are covered with biological fluids during plasma treatment, studies point out an implication of the liquid media in the effects of plasmas. Within this context, in this research project the effect of an atmospheric pressure plasma jet will be investigated in two different liquid media by implementing appropriate measurement protocols for three different reactive species: $\left[\mathrm{H}_{2} \mathrm{O}_{2}\right] ;\left[\mathrm{HO}^{\bullet}\right]$ and $\left[\mathrm{NO}_{2}^{-}\right]$. To ascertain its biological effects this atmospheric pressure plasma jet treated liquids will be put in contact with bone cancer cells (SaOs-2) and also with healthy bone cells (Hobs). Preliminary results show that the atmospheric pressure plasma jet treated liquids contain different amounts of the studied reactive species depending on the treatment conditions and the medium employed, and can selectively kill bone cancer cells while conserving the viability of healthy bone cells.
\end{abstract}

Keywords: Plasma, liquids, reactive species, cells, bone cancer.

\begin{abstract}
Resumen
En los últimos años se ha empezado a desarrollar una posible terapia contra el cáncer mediante plasmas frios a presión atmosférica. Los efectos celulares que se han observado (toxicidad selectiva de células de cáncer frente a células sanas) indican una posible implicación de los líquidos tratados con plasma. El objetivo del presente trabajo es el de investigar los efectos del plasma a presión atmosférica en medios de cultivo celulares, en cuanto a la generación de distintas especies reactivas y sus posibles efectos en células óseas tanto sanas como cancerígenas. Se trataron dos medios de cultivo con un haz de plasma de helio a presión atmosférica y se determinaron tres especies reactivas $\left[\mathrm{H}_{2} \mathrm{O}_{2}\right],\left[\mathrm{NO}_{2}^{-}\right]$y $\left[\mathrm{HO}^{\bullet}\right]$ de manera cuantitativa. Se evaluó la citotoxicidad de un medio de cultivo tratado en células óseas cancerígenas ( $\mathrm{SaOs}$-2) y sanas (Hobs). Los resultados muestran la generación progresiva de distintas especies reactivas en función del tiempo de tratamiento con plasma y son las principales responsables de la muerte celular de células de cáncer de forma selectiva.
\end{abstract}

Palabras clave: Plasma, líquido, especies reactivas, células, cáncer de hueso.

Correspondencia:

Cristina Canal.

E-mail: cristina.canal@upc.edu

DOI: $10.5821 / \mathrm{sibb} .25 .1 .5384$ 


\section{Introduction}

During the last years a significant attention has been paid to the biomedical applications of Atmospheric Pressure Plasmas (APP). Some researchers point out that plasma properties selectively kill cancer cells without damaging the surrounding healthy tissues [1]. In fact, new APP devices were specially developed for biomedical applications. Plasmas generated at atmospheric pressure in APP devices can be directly touched by humans or be in contact with human tissues; hence it must be as safe as possible. These devices are a big source of a number of reactive species that can react with soft materials or liquids [2]. Plasma can be defined as a fully or partially ionized gas consisting of positive and negative ions, free electrons, free radicals, UV and visible radiation. It does not usually exist on the natural environment but can be artificially generated from neutral gases [3].

Cold Atmospheric Plasma (CAP) is an improvement of the atmospheric plasma, where ion temperature is close to the room temperature that makes it attractive for biomedical applications [4]. Traditionally, CAP has been used for the surface treatment of materials and more recently for treatment of liquids, like in decontamination of water [5]. Furthermore, this technology allows treating living or heatsensitive surfaces, which makes this type of plasma useful for treatment of biological tissues [6]. Actually, this type of plasma has been developed for biomedical applications. CAP have been evaluated in the sterilization of infected tissues, inactivation of microorganisms, wound healing, skin regeneration, blood coagulation, tooth bleaching and cancer therapy [7]. Different CAP sources can be directly applied to cancer cells. Therefore, the charged particles, electrical fields and reactive species produced by plasma can act on biological cells [8]. Alternatively, they can be used to treat liquid media, thereby generating plasma-activated medium (PAM), which is applied to the cancer cells afterwards. The plasma chemistry leads to the generation of an abundance of high secondary long living species. These species come from a first reaction between the gas-liquid interface interaction. Many of the radicals generated during the discharge can contribute to complex reactions: formation of other short and long-lived species in the solution [9]. In fact, more reactive species are generated for the APP technique in comparison to other plasma sources [10]. Although the mechanisms involved in the biological action of plasmas, are not well understood, reactive species generated are known to be biological active [11].

Cancer therapy is one of the most promising applications of APP, as their efficacy was demonstrated in vitro and in vivo for various cancer types of soft tissues [12-15]. Many active species generated by APP that include charged particles, radical, UV radiations among others, can interact with living materials. Researchers point out the responsibility of the multitude of reactive species generated by APP that may provide significant advantages over cancer therapies. During the last decade, the anticancer capacity of APP has been illustrated in cancer cell lines of breast, skin, lung, pancreas, cervix and brain but not in bone cancer cells, except in our previous study [16]. As this is a novel field of study, scarce information is available in the literature to explain the mechanism by which the plasmas interact with cells. Some researchers $[17,18]$ point out the role of reactive oxygen and nitrogen species (RONS) generated by APP which are supposed to be key players in this process. In fact, an excess of oxidative stress causes a disturbance of the cell oxidative balance [19]. Excessive production of oxidative stress molecules, exceeding the cellular antioxidative mechanism, can lead to cell death in both normal and aberrant cells by activating intracellular signalling pathway [20]. However, in contrast to healthy cells, tumour cells contain higher steady state RONS concentrations and bear malfunctioning antioxidant mechanisms that lead to the cell death. The increase of RONS concentration can be used as an effective and selective treatment against cancer [21].

The main aim of this work is to evaluate the potential of the APPJ treated liquids for bone cancer therapy. Therefore, to evaluate the effects of APPJ on the generation of RONS in 
different liquid media is of interest and how this relates to PAM effects on bone cancer and healthy cells will be investigated.

\section{Materials and methods}

\section{Cell Culture}

Two different types of cells were studied and grown in their own medium before any treatment. One kind of cancer cell was employed:

Sarcoma Osteogenic human cells lines (SaOs-2, ATCC, USA), passages 10-14, were grown in Mc Coy's 5A medium (Sigma Aldrich) supplemented with $10 \%$ of fetal bovine serum (FBS), $2 \mathrm{mM}$ of L-glutamine, penicillin/ streptomycin $(50 \mathrm{U} / \mathrm{mL}$ and $50 \mu \mathrm{g} / \mathrm{mg}$, respectively) and $2 \mathrm{mM}$ of sodium pyruvate (all from Invitrogen).

The healthy cells employed were Human osteoblast primary cells (Hobs, 406-05A, Sigma-Aldrich, USA), passages 1-2, that were grown in Growth osteoblast medium (Life Technologies).

Advanced Dulbeccos's Modified Eagle Medium (AdvDMEM, Life technologies) supplemented with $10 \%$ of FBS, 2 mM of L-glutamine and penicillin/streptomycin $(50 \mathrm{U} / \mathrm{mL}$ and $50 \mu \mathrm{g} / \mathrm{mg}$, respectively) was used for the APPJ treatments.

All mediums were prepared before use and all types of cells were maintained at $37^{\circ} \mathrm{C}$ in a humidified atmosphere containing $5 \%$ of $\mathrm{CO}_{2}$.

\section{Plasma set-up}

The APPJ set-up used here was a homemade plasma [22].The discharge electrode was a copper wire with a diameter $(\phi)$ of $1 \mathrm{~mm}$ inserted in a $\phi 1.2 \mathrm{~mm}$ inner quartz capillary tube covered by a polytetrafluoroethylene holder. The electrode was connected to a high voltage power (Conrad Electronics, $6 \mathrm{~W}$ power consumption) to generate the discharge. The gas employed was helium (He, 5.0 Linde, Spain) and the gas flow was regulated by a flow controller (Bronkhorst Mass View).

\section{Treatment conditions}

To determine the generation of RONS, Mc Coy and AdvDMEM cell culture media were studied. $4 \mathrm{ml}$ of Mc Coy and AdvDMEM medium respectively were contained in $2 \mathrm{~cm}$ petri dish and APPJ was applied directly on it for different times (10;20 and $30 \mathrm{~min})$. All the samples were on triplicate and all tests were triplicate.

All the liquid samples were treated with a 5 $\mathrm{L}_{\mathrm{n}} /$ min flow with a constant working distance of $20 \mathrm{~mm}$. The treatment time was scaled depending on the volume and surface of liquid to be treated, according to the following equation:

$\mathrm{t}_{\text {indirect treatment }}=\frac{\text { surface petridish } \bullet \text { tdirect treatment }}{\text { surface well }(96)}$

For the cell culture, $1.10^{4}$ cells were seeded in a 96 well-plate and incubated during $24 \mathrm{~h}$ with fresh medium before treatment. The APPJ treatment was on $4 \mathrm{ml}$ of AdvDMEM medium during 10; 20 and $30 \mathrm{~min}$. Then, only $150 \mu \mathrm{l}$ of plasma treated medium was replaced into cells.

\section{Cytotoxicity}

The cell viability was determined by a colorimetric method [23] using the quantification of cells by the lactate dehydrogenase activity (Detection kit, LDH purchased from Roche Applied Science). Measurement were operated at $72 \mathrm{~h}$ post plasma treatment. Cells were lysed by removing the culture medium and adding $100 \mu \mathrm{l}$ of Mammalian Protein Extraction Reagent (M-PER, Thermo-Scientific). A negative and a positive control were also evaluated. The negative control corresponds to an untreated culture medium with no cells. While, the positive control refers to the corresponding cell type with untreated medium; it was employed as a reference for $100 \%$ cell viability. The absorbance was measured at a wavelength $(\lambda)$ of $492 \mathrm{~nm}$ with a micro-plate reader (Synergy HTX, BioTek) and the percentage cell viability was determined as follows:

$\%$ cell viability $=\frac{\text { sample }- \text { negative control }}{\text { positive control - negative control }}$

\section{Detection of reactive species}

Nitrites: the nitrite concentration $\left[\mathrm{NO}_{2}{ }^{-}\right]$ was determined by adding $50 \mu \mathrm{l}$ of Griess reagent $[24,25]$ to $50 \mu \mathrm{l}$ sample introduced in 96 
well-plates. The Griess reagent was obtained by dissolving $1 \% \mathrm{wt} / \mathrm{v}$ sulfanilamide (M.W: 172.20 g/mol; Sigma-Aldrich; powder form), $0.1 \% \quad \mathrm{wt} / \mathrm{v} \quad \mathrm{N}-(1$-naphtyl)ethylenediamine (NEED, M.W: 172.20 g/mol; Sigma-Aldrich; powder form) and $5 \% \mathrm{wt} / \mathrm{v}$ phosphoric acid (85 \%; M.W: 98 g/mol; Pancreac) in de-ionized water $\left(\mathrm{H}_{2} \mathrm{O}_{\mathrm{d}}\right)$ [26]. The plates were incubated for $10 \mathrm{~min}$ at room temperature protected from light. The absorbance was measured at $\lambda$ of $540 \mathrm{~nm}$. The $\left[\mathrm{NO}_{2}^{-}\right]$in each sample was calculated by using a calibration curve with $\mathrm{NaNO}_{2}$ (M.W: 69 g/mol; powder form, SigmaAldrich) solution in the studied medium.

Peroxides: the concentration of peroxides $\left[\mathrm{H}_{2} \mathrm{O}_{2}\right]$ was evaluated by a colorimetric method resulting of the reaction of $\mathrm{H}_{2} \mathrm{O}_{2}$ with titanyl sulphate by measuring the absorbance at $\lambda$ of $407 \mathrm{~nm}$ [27]. $100 \mu \mathrm{l}$ of the sample were placed in a 96 well plate and $10 \mu \mathrm{l}$ of $\mathrm{NaN}_{3}$ (M.W: 65 g/mol; Sigma-Aldrich; powder form) solution at $60 \mathrm{mM}$ were added to neutralise potential nitrites and nitrates present in the sample that can interact with peroxides [28]. Then $50 \mu \mathrm{L}$ of $\mathrm{TiSO}_{4}$ reagent (M.W: $159.90 \mathrm{~g} / \mathrm{mol} ; 15 \%$ wt in $\mathrm{H}_{2} \mathrm{SO}_{4}$ ) were added. The reaction is immediate and remains stable over $6 \mathrm{~h}$. $\left[\mathrm{H}_{2} \mathrm{O}_{2}\right]$ concentration level in each sample was determined using a calibration curve with hydrogen peroxide $\left(\mathrm{H}_{2} \mathrm{O}_{2} ; \mathrm{M} . \mathrm{W}: 34.01 \mathrm{~g} / \mathrm{mol} ; 30 \% \mathrm{wt} / \mathrm{wt}\right.$ in $\mathrm{H}_{2} \mathrm{O}$; Sigma-Aldrich) solution in each studied medium.

Hydroxide radical: to determine free hydroxyl radical concentration $\left[\mathrm{HO}^{\circ}\right]$, an indirect method was employed [29]. The degradation of methylene blue (MB; M.W: 373.90 $\mathrm{g} / \mathrm{mol}$; Sigma-Aldrich; powder form) was followed to evaluate the hydroxide radical concentration $\left[\mathrm{HO}^{\bullet}\right]$ generated by APPJ. MB solutions of $0.03 \mathrm{~g} / \mathrm{l}$ were prepared, and after plasma treatment, the absorbance was measured at $\lambda$ of $664 \mathrm{~nm}$. The MB concentration was determined using a calibration curve with $\mathrm{MB}$ solution in the corresponding liquid medium evaluated.

\section{Results}

\section{Detection of reactive species}

The effects of APPJ on two different cell cul- ture media were evaluated with regard to the generation of RONS. The generation of peroxides $\left[\mathrm{H}_{2} \mathrm{O}_{2}\right]$, nitrites $\left[\mathrm{NO}_{2}^{-}\right]$and the decrease of $[\mathrm{MB}]$ concentration - which is related to the amount of $\left[\mathrm{HO}^{\circ}\right]$ - were measured following APPJ treatment as a function of the treatment time. In fig.1, two liquid media usually employed for cell culture were compared depending on the APPJ treatment time. It can be observed that the concentration of $\left[\mathrm{H}_{2} \mathrm{O}_{2}\right]$ and $\left[\mathrm{NO}_{2}\right]$ was progressively increasing, while the $\mathrm{MB}$ concentration was decreasing as a function of the treatment time with APPJ in both media evaluated. Differences in the response of both media studied were recorded: In AdvDMEM medium more peroxides were generated than in Mc Coy medium (fig.1.a)). Five times more peroxides were formed in each media than nitrites. It is shown in fig.1.b) that more nitrites are generated in Mc Coy medium than in AdvDMEM medium. MB shows a decreasing concentration with increasing treatment time and is similar for both cell culture media with the APPJ treatment time. Similar results were found when treating low volumes $(2 \mathrm{ml})$ of liquid in a smaller surface $\left(1 \mathrm{~cm}^{2}\right)$ with shorter APPJ treatment times (5; 10 and $15 \mathrm{~min}$ ), as in greater volume of liquid $(4 \mathrm{ml})$ in a bigger surface, as roughly the same amount of RONS was generated (fig.1). Conversely, with much lower volumes, $150 \mu \mathrm{l}$ of liquid media were treated at much shorter APPJ times of $0.5 ; 1$ and $1.5 \mathrm{~min}$. In that case, even if the generation of RONS follows the same trend, the effective concentration generated by APPJ is much lower than in the case of treatment of higher volumes.

\section{Cytotoxicity}

The effect of plasma treated liquid was evaluated on both cancer and healthy bone cells. To ascertain the influence of the modification produced in the liquid media by the plasma treatment, the PAM was transferred onto adherent bone cancer cells (SaOs-2), and bone healthy cell (Hobs) immediately after treatment. APPJ treatment of $4 \mathrm{ml}$ of AdvDMEM media and $150 \mu$ of these treated media were transferred on the top of the cells and the viability was measured after $72 \mathrm{~h}$. The 
results are reported with respect to a positive control of the cells without plasma treated medium which are set as the $100 \%$ viability. Fig. 2 shows that the plasma treated liquid in contact with cells reduces the cell viability, the more the longer the plasma treatment time. In contrast, the plasma treated liquid doesn't affect the viability of the healthy cells (viability between $92 \%$ and $98 \%$ ). It can also be observed that cells are affected by the RONS doses/ treatment time; cancer cells viability decrease from $50 \%$ to $5 \%$ in treatment times ranging from 10 to $30 \mathrm{~min}$.

\section{Discussion}

The diffusion of reactive species produced by the reaction formed at the plasma-liquid interface leads to some reactions and processes which depend on the nature of the liquid as shown in fig.3. Reactive species generated by plasma are the result of a cascade of reactions created with the interaction plasma-liquid medium [30]. The concentration increase of RONS measured $\left(\left[\mathrm{H}_{2} \mathrm{O}_{2}\right]\right.$ and $\left.\left[\mathrm{NO}_{2}^{-}\right]\right)$was related to the plasma treatment time and the chemical composition of the medium. The $[\mathrm{MB}]$ decrease may be related to the generation of $\left[\mathrm{HO}^{\bullet}\right]$ in the medium by the decomposition of the MB (fig.1c) and previously reported in the literature [31]. The APPJ generates reactive species directly at the gas-liquid interface which react with the liquid composition. The reactive species amount is controlled through the gas used for the plasma discharge and also the liquid medium composition

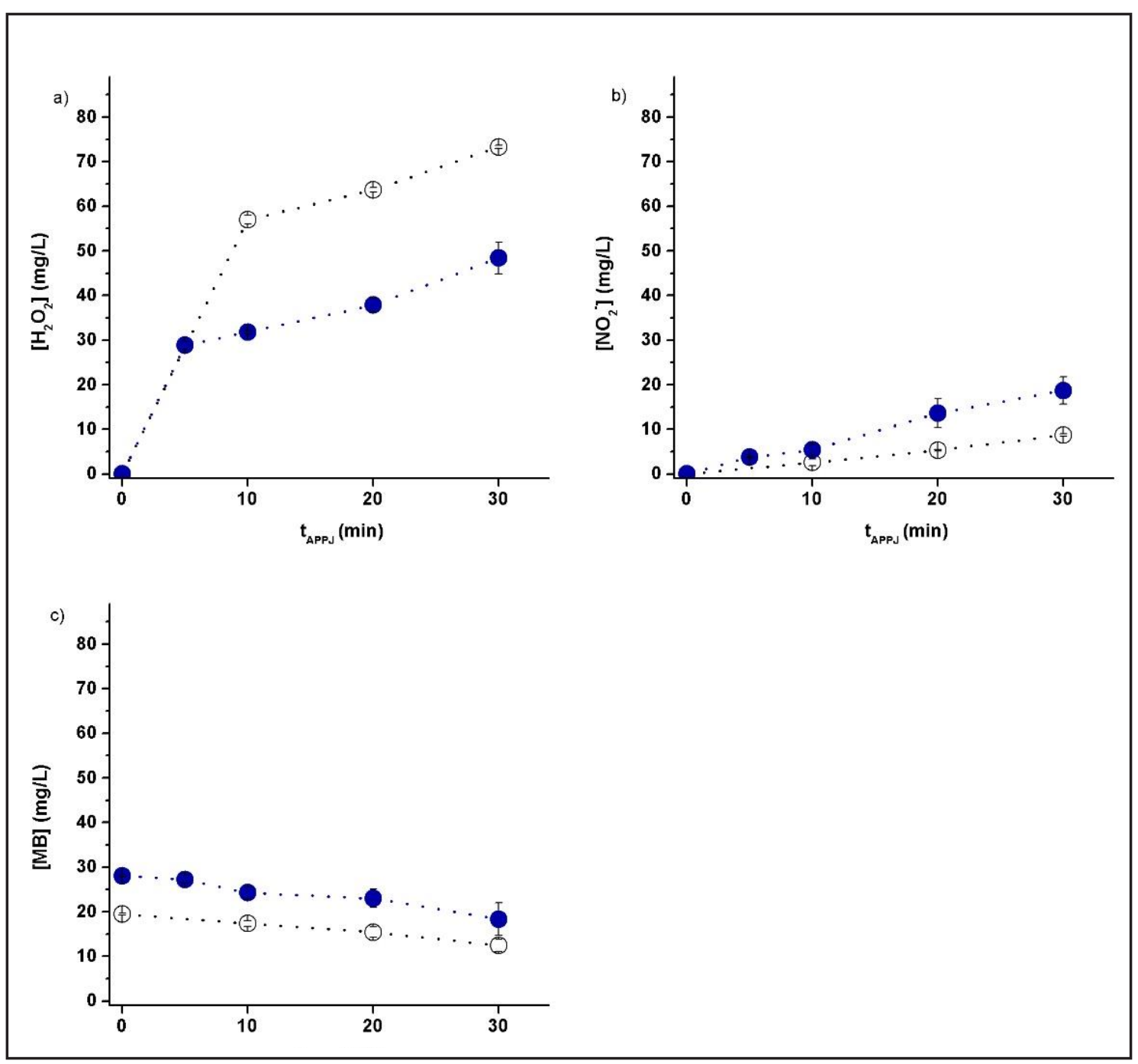

Figure 1. Evaluation of the generation of RONS in $4 \mathrm{ml}$ of Mc Coy (blue full dot) and AdvDMEM (empty dot) cell culture media following APPJ treatment: a) $\left[\mathrm{H}_{2} \mathrm{O}_{2}\right]$; b) $\left[\mathrm{NO}_{2}^{-}\right]$and c) $[\mathrm{MB}]$. 
plays an important role [32]. It is observed in this work a progressive formation of $\mathrm{H}_{2} \mathrm{O}_{2}$ and $\mathrm{NO}_{2}{ }^{-}$in both cell culture media studied (Mc Coy and AdvDMEM) (fig.1.a) and b)) with APPJ treatment time. The creation of many other species can be expected through the contact of liquid with APPJ, considering the complex composition of the cell culture media. In fact, in addition to the species measured here $\left(\mathrm{H}_{2} \mathrm{O}_{2}, \mathrm{NO}_{2}^{-}\right.$and indirectly $\left.\mathrm{HO}^{\bullet}\right)$ many other RONS have been described and may be formed. In this kind of cell culture

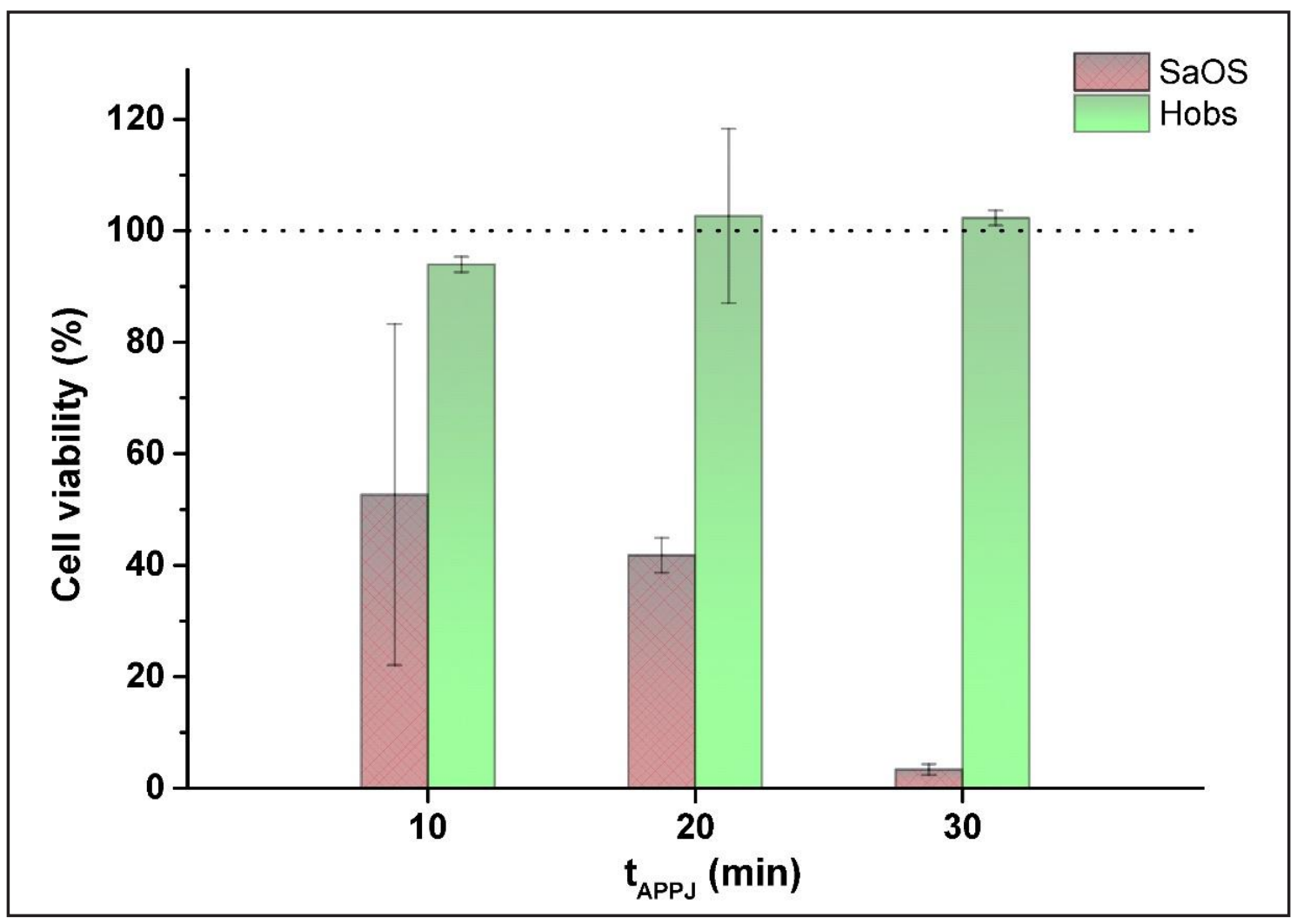

Figure 2. Cell viability of bone cancer cells (SaOs-2, red dense bar) and bone healthy cell (Hobs, green bar) in contact with APPJ treated medium ( $4 \mathrm{ml}$ of AdvDMEM medium) following $72 \mathrm{~h}$ of incubation in contact with this medium.

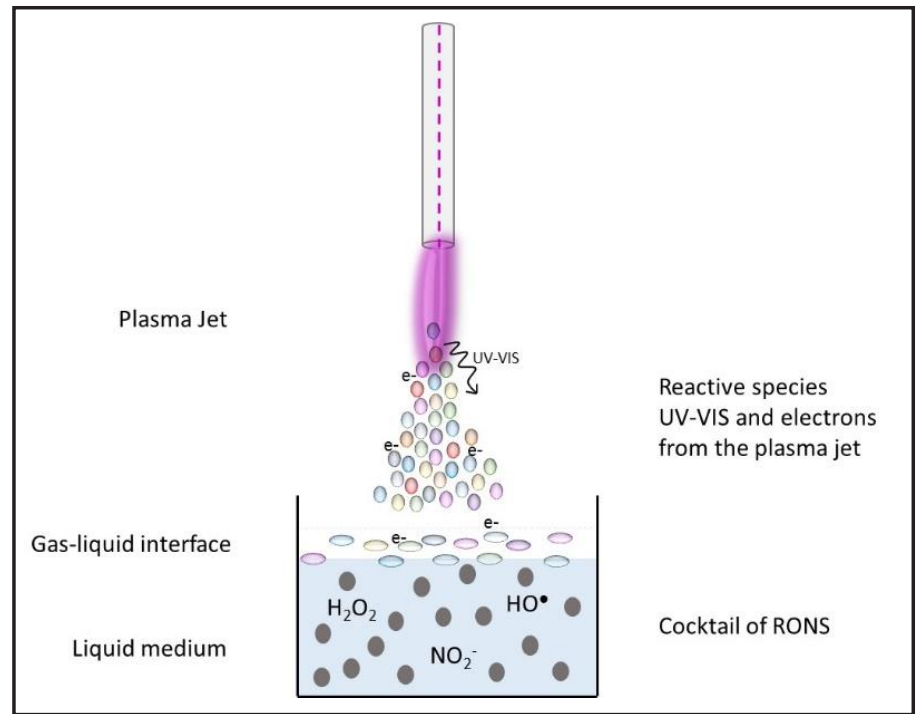

Figure 3. Scheme of the interaction of atmospheric plasmas with liquids, with spheres representing the different reactive species. 
media, proteins and sugars, among others, present in the medium composition can be decomposed by the electrical discharge from the APPJ and also by chemical decomposition or reaction from the radicals formed during the process. Especially, positive and negative ions from the post-discharge largely combine or neutralize prior to diffusing into the liquid. Moreover, lifetimes of this neutral radicals are much longer, so that these reactive species are able to diffuse into liquids without significant losses [33].

The determination of long-living species generated by APPJ in the liquid media produced by a cascade of reactions the interface gas/liquid was useful to start understanding and identifying the processes beyond the behaviour of cells following exposure to plasma treated media.

The cytotoxicity of PAM on both cancer and healthy bone cells was investigated to ascertain potential selective effects of the APPJ treated media. The APPJ treated liquid media were effective in selectively killing bone cancer cells. Therefore, the aqueous state of the RONS in generated by plasma clearly play an important role in the anti-tumour effects as shown in other works [34]. As shown here, liquids can mediate the cytotoxicity effects of APPJ towards cancer cells, as in the biological environment, cells are covered by physiological liquids. In literature, direct treatment of cancer cells with plasmas has been shown effective, but also in some cases, treating cell culture media or liquid medium showed to be an effective anti-tumour fluid in vitro and in vivo [35]. Our results confirm the efficiency of treatment of liquids with APPJ for cancer cell death. Two effects can be highlighted; First, it can be observed that there is a significant decrease in the viability of cancer cells (50 \% for the SaOs-2) for the shortest treatment time of $10 \mathrm{~min}$, and down to $5 \%$ of viability for $30 \mathrm{~min}$ treatment of the liquid medium. This decrease in cell viability is comparable to that found in other studies focused also in bone cancer cells but following chemotherapeutical approaches [36]. Secondly, the healthy osteoblastic cells Hobs, treated in the same condition were completely viable and unaffected by the trea- ted liquid.

This result highlights one of the advantages of this indirect treatment with APPJ treated medium, as it avoids the effects of electric fields, UV light, etc. that might potentially have harmful effects on healthy cells if uncontrolled. This treatment of liquids with plasma allows only the long living reactive species generated from APPJ or metastable species produced in reactions of the plasma with the liquid to interact with cells. It has been shown in literature that in fact, RONS generated in the liquid media can promote oxidative stress and trigger different signaling pathways in cells.

\section{Conclusions}

Atmospheric pressure plasma jet generates different gaseous reactive species that were transmitted to the liquid phase through formation of secondary species. Protocols have been successfully implemented to determine the $\left[\mathrm{H}_{2} \mathrm{O}_{2}\right],\left[\mathrm{NO}_{2}^{-}\right]$and $\left[\mathrm{HO}{ }^{\bullet}\right]$ reactive species generated during the APPJ treatment of liquid media. This has allowed recording a time-dependent increase in the amount of these species in cell culture medium due to plasma treatment, which depend on the volume of liquid treated, as well as on the chemical composition of the cell culture medium treated. This cocktail of reactive species generated by APPJ exhibits lethal effects selectively towards bone cancer cells without harmful effects for healthy bone cells. The APPJ treated cell culture media is cytotoxic to bone cancer cells, producing a cell viability reduction between 50 and 95\% depending on the RONS doses. Healthy cells remain fully viable after the same treatment. Therefore, this indirect methodology may be considered as being effective and selective, and avoiding electric fields like UV radiation of the APPJ. The lethal effects seem to be related with the RONS activity in the liquid media into the cells.

\section{Aknowledgments}

Authors acknowledge the financial support of MAT2015-65601-R project (MINECO/ 
FEDER, EU) and of SGR2014 01333. This project has received funding from the European Research Council (ERC) under the European Union's Horizon 2020 research and innovation programme (Grant agreement No 714793). CC acknowledges MINECO for the Ramon y Cajal fellowship. JGM thanks the support of the AGAUR of the Government of Catalonia (2014-PDJR- 00014). Support for the research of MPG was received through the ICREA Academia Award for excellence in research, funded by the Generalitat de Catalunya.

\section{References}

1. Keidar, M. et al. Cold atmospheric plasma in cancer therapy. Phys. Plasmas 20, 57101 (2013).

2. Weltmann, K.-D. et al. Plasma Processes and Plasma Sources in Medicine. Contrib. to Plasma Phys. 52, 644-654 (2012).

3. Schutze, A. et al. The atmospheric-pressure plasma jet: a review and comparison to other plasma sources. IEEE Trans. Plasma Sci. 26, 1685-1694 (1998).

4. Fridman, G. et al. Applied Plasma Medicine. Plasma Process. Polym. 5, 503-533 (2008).

5. Stoffels, E., Flikweert, A. J., Stoffels, W. W. \& Kroesen, G. M. W. Plasma needle: a non-destructive atmospheric plasma source for fine surface treatment of (bio)materials. Plasma Sources Sci. Technol. 11, 383-388 (2002).

6. Laroussi, M. Low-Temperature Plasmas for Medicine? IEEE Trans. Plasma Sci. 37, 714-725 (2009).

7. Laroussi, M. Low-Temperature Plasma Jet for Biomedical Applications: A Review. IEEE Trans. Plasma Sci. 43, 703-712 (2015).

8. Zhao, S. et al. Atmospheric Pressure Room Temperature Plasma Jets Facilitate Oxidative and Nitrative Stress and Lead to Endoplasmic Reticulum Stress Dependent Apoptosis in HepG2 Cells. PLoS One 8, (2013).

9. Bruggeman, P. J. et al. Plasma-liquid interactions: a review and roadmap. Plasma Sources Sci. Technol. 25, 53002 (2016).

10. Lu, X. et al. Reactive species in non-equilibrium atmospheric-pressure plasmas: Generation, transport, and biological effects. Phys. Rep. 630, 1-84 (2016).

11. Oh, J. S. et al. How plasma induced oxidation, oxygenation, and de-oxygenation influences viability of skin cells. Appl. Phys. Lett. 109, (2016).

12. Torii, K. et al. Effectiveness of plasma treatment on gastric cancer cells. Gastric Cancer 18, 635643 (2015).

13. Utsumi, F. et al. Selective cytotoxicity of indirect nonequilibrium atmospheric pressure plasma against ovarian clear-cell carcinoma. Springerplus 3, 398 (2014).

14. Utsumi, F. et al. Effect of Indirect Nonequilibrium Atmospheric Pressure Plasma on AntiProliferative Activity against Chronic Chemo-Resistant Ovarian Cancer Cells In Vitro and In Vivo. PLoS One 8, e81576 (2013).

15. Tanaka, H. et al. Plasma-Activated Medium Selectively Kills Glioblastoma Brain Tumor Cells by Down-Regulating a Survival Signaling Molecule, AKT Kinase. Plasma Med. 1, 265-277 (2011).

16. Canal, C. et al. Plasma-induced selectivity in bone cancer cells death. Free Radic. Biol. Med. 110, (2017).

17. Ratovitski, E. A. et al. Anti-Cancer Therapies of 21st Century: Novel Approach to Treat Human Cancers Using Cold Atmospheric Plasma. Plasma Process. Polym. 11, 1128-1137 (2014).

18. Graves, D. B. Reactive Species from Cold Atmospheric Plasma: Implications for Cancer Therapy. Plasma Process. Polym. 11, 1120-1127 (2014).

19. Trachootham, D., Alexandre, J. \& Huang, P. Targeting cancer cells by ROS-mediated mechanisms: a radical therapeutic approach? Nat. Rev. Drug Discov. 8, 579-591 (2009).

20. Bauer, G. \& Graves, D. B. Mechanisms of Selective Antitumor Action of Cold Atmospheric Plasma-Derived Reactive Oxygen and Nitrogen Species. Plasma Process. Polym. 13, 1157-1178 (2016).

21. Wiseman, H. \& Halliwell, B. Damage to DNA by reactive oxygen and nitrogen species: role in inflammatory disease and progression to cancer. Biochem. J. 313 ( Pt 1), 17-29 (1996).

22. Zaplotnik, R. et al. Influence of a sample surface on single electrode atmospheric plasma jet parameters. Spectrochim. Acta Part B At. Spectrosc. 103-104, 124-130 (2015).

23. Koh, J. Y. \& Choi, D. W. Quantitative determination of glutamate mediated cortical neuronal injury in cell culture by lactate dehydrogenase efflux assay. J. Neurosci. Methods 20, 83-90 (1987).

24. Giustarini, D., Rossi, R., Milzani, A. \& DalleDonne, I. Nitrite and Nitrate Measurement by Griess Reagent in Human Plasma: Evaluation of Interferences and Standardization. Methods Enzymol. 440, 361-380 (2008).

25. Guevara, I. et al. Determination of nitrite/nitrate in human biological material by the simple Griess reaction. Clin. Chim. Acta 274, 177-188 (1998).

26. Granger, D. L., Taintor, R. R., Boockvar, K. S. \& Hibbs, J. B. Measurement of nitrate and nitrite in biological samples using nitrate reductase and Griess reaction. Methods Enzymol. 268, 142-51 (1996).

27. Machala, Z. et al. Formation of ROS and RNS in Water Electro-Sprayed through Transient Spark Discharge in Air and their Bactericidal Effects. Plasma Process. Polym. 10, 649-659 (2013). 
28. Satterfield, C. N. \& Bonnell, A. H. Interferences in Titanium Sulfate Method for Hydrogen Peroxide. Anal. Chem. 27, 1174-1175 (1955).

29. Chen, Z., Lin, L., Cheng, X., Gjika, E. \& Keidar, M. Effects of cold atmospheric plasma generated in deionized water in cell cancer therapy. Plasma Process. Polym. 13, 1151-1156 (2016).

30. Lukes, P. \& Locke, B. R. Plasmachemical oxidation processes in a hybrid gas-liquid electrical discharge reactor. J. Phys. D. Appl. Phys. 38, 4074-4081 (2005).

31. Chandana, L., Manoj Kumar Reddy, P. \& Subrahmanyam, C. Atmospheric pressure non-thermal plasma jet for the degradation of methylene blue in aqueous medium. Chem. Eng. J. 282, 116-122 (2015).

32. Lukes, P., Dolezalova, E., Sisrova, I. \& Clupek, M. Aqueous-phase chemistry and bactericidal effects from an air discharge plasma in contact with water: evidence for the formation of peroxynitrite through a pseudo-second-order postdischarge reaction of $\mathrm{H}_{2} \mathrm{O}_{2}$ and $\mathrm{HNO}_{2}$. Plasma Sources Sci. Technol. 23, 15019 (2014).

33. Rumbach, P., Bartels, D. M., Sankaran, R. M. \& Go, D. B. The solvation of electrons by an atmospheric-pressure plasma. Nat. Commun. 6, 7248 (2015).

34. Mohades, S., Barekzi, N., Razavi, H., Maruthamuthu, V. \& Laroussi, M. Temporal evaluation of the anti-tumor efficiency of plasma-activated media. Plasma Process. Polym. 13, 1206-1211 (2016).

35. Anti-tumor aqueous solution, anti-cancer agent, and methods for producing said aqueous solution and said anti-cancer agent. (2013).

36. Zou, J. et al. Sensitization of Osteosarcoma Cell Line SaOS-2 to Chemotherapy by Downregulating Survivin. Arch. Med. Res. 41, 162-169 (2010). 